\title{
Reproductive Choices in Gibraltar: A Case Study of a Community In Transition, 1960-1996
}

\author{
Stacie D.A. Burke \\ Department of Anthropology \\ University of Manitoba \\ Winnipeg, Manitoba, Canada \\ burkes@cc.umanitoba.ca
}

Lawrence A. Sawchuk

Department of Social Sciences, Anthropology

University of Toronto at Scarborough

Scarborough, Ontario, Canada

\begin{abstract}
Times of social disruption and change unsettle community equilibrium and represent important transition points. This research examines the 15-year border closure between Spain and Gibraltar and its subsequent reopening in 1985 in reshaping the community opportunity structure, particularly women's employment, education, and housing. The study examines 3284 births which occurred in the community between 1960 and 1996, noting a general rise in premarital conceptions in the community. This research compares life course decisions among marital and premarital conceivers over time, stressing important changes in the community's ecological setting and the powerful role of political disturbances in structuring those changes.
\end{abstract}

Key Words: Marriage; first childbirth; conception; Gibraltar 
Stacie D. A. Burke and Lawrence A. Sawchuk

\section{Résumé}

Les périodes de bouleversements sociaux déstabilisent les communautés et représentent des points de transition importants. Cette étude examine les 15 ans de la fermeture de la frontière entre l'Espagne et Gibraltar et sa réouverture en 1985 ainsi que son rôle dans la réorganisation de la structure d'opportunité de la communauté, particulièrement pour ce qui est de la participation des femmes à la main d'œuvre, l'éducation et le logement. L'étude examine 3284 naissances de la communauté entre 1960 et 1996, et y remarque une hausse des grossesses prénuptiales. Cette recherche compare les décisions de parcours de vie chez les personnes enceintes mariées et non mariées au fil du temps, en soulignant les changements importants dans le cadre écologique de la communauté et le rôle crucial des perturbations politiques dans la structuration de ces changements.

Mots clés: Mariage, première naissance, conception, Gibraltar

\section{Introduction}

Times of social disruption and change, marked by events such as war, political unrest, famine, epidemic disease, and natural disaster, generally unsettle community equilibrium and represent important transition points for changing attitudes and behaviours. Within this context, normative codes of behaviour concerning marriage, childbearing and other life course decisions may be redefined, either by choice or by necessity. We turn to the small-scale urban British overseas territory of Gibraltar for the opportunity to examine the effects of rapid community-wide social change on life course decisions among young couples. Between 1969 and 1985, Gibraltar effectively became an 'island' population as the border gates between socialist Spain and democratic Gibraltar slammed shut. Over the fifteen years that the border gates stood closed Gibraltar became a very different and notably insular community. During the time of the border closure Sawchuk (1992) found that marriage behaviour changed dramatically, with couples entering into marriage at significantly younger ages than had previously been observed. This article will expand on these earlier findings, further scrutinizing life course decision making before, during, and after the border closure. 


\section{Reproductive Choices in Gibraltar: A Case Study of a Community under Transition, 1960-1996}

Many community studies have engaged similar dramatic points of change to evaluate the open, flexible, and dynamic quality underpinning life course decision making. Haldre et al. (2005) examined rapid changes in teenage reproductive behaviour emerging in Estonia after the country regained its independence in 1991. Most notable is their observation that the country's abortion rate rose dramatically among adolescents who became pregnant after 1991. The authors argue that the shift occurred because of new postindependence opportunities for adolescents and young adults which offset the previous attraction to early marriage and childbearing. In an American example, Cooksey et al. (1996) targeted the outbreak of the AIDS pandemic as a staging point for changing attitudes regarding sexual relationships among adolescents. Numerous researchers have investigated the effects of major social and political upheavals on the changing demographic and family-building qualities in the former Soviet Union (see, for example, Agadjanian and Makarova, 2003; Hitztaler, 2004; Kohler and Kohler, 2002; Scherbov and Van Vianen, 2001). Agadjanian and Makarova (2003:452) suggest that age at marriage, the marriage to first birth interval, and the first to second birth interval are three "sensitive demographic barometers of people's perception of and adjustment to changes in their social milieu"; they argue all three markers will be delayed when a community is faced with "upheaval".

In a recent article, Ravanera and Rajulton (2006:181) outline several important early life course events which serve to define the transition of an individual into adulthood, including: completion of schooling, start of regular work, entry into marriage, and the birth of the first child. Ravanera and Rajulton (2006) note important age-related changes occurring in the timing of these life events among Canadian woman over time, including the increasing delay in the birth of the first child among those born since the 1960s and onwards, but also important changes in the "normative sequence" of these events. The authors outline graduation $\rightarrow$ work $\rightarrow$ marriage $\rightarrow$ motherhood as the " "normatively" preferred pathway to motherhood", noting that the probability of this pathway is uniformly high among higher SES women (and strengthening over time), but is also increasing among woman of all SES groups. A second pathway, work $\rightarrow$ marriage $\rightarrow$ motherhood, was more commonly observed among women of low and middle SES, but declining over time (among more recent birth cohorts). A third pathway of marriage $\rightarrow$ motherhood was most commonly observed among low SES women, but also significantly declining over time. According to Ravanera and Rajulton (2006:197), "women with lower social status are more likely to go through shorter routes to motherhood, including the trajectory that bypasses post-secondary education, regular work, and marriage". In considering the complex factors that may account for these different trajectories, the authors believe that opportunities for higher education and employment may account for 
the different trajectories and timing of motherhood but also stress the importance of the perceived value placed in motherhood.

We further these arguments, suggesting that community-level factors and opportunity structures which, along with individual-level factors, underlie important decisions concerning the sequencing of life course events may be may be fueled by larger-scale transitional events experienced by the community as a whole. In so doing, pathways to adulthood including marriage and parenting may be redefined and retimed. Billy et al. (1994) single out community socioeconomic status, defined by i) income and poverty levels, ii) housing conditions and values, and iii) educational attainment, as one of the most important factors shaping sexual and reproductive decision making among the young. Where there is the perception of limited opportunities, the young "may see little reason to defer gratification or plan for the future" (Billy et al., 1994:389). Furthermore, when a community places a high value on parenthood, Cooksey (1990) argues that an elevated status may be achieved through childbirth, even if the parents are young. When opportunities outside of marriage expand, on the other hand, rising employment and educational aspirations may downplay relationships among the young, as Carmichael (1996) has observed for Australia. If the community dynamic itself presents a significant force shaping sexual and reproductive decision making, then it is essential to consider the impact of larger forces which change communities, such as those embodied during times of social disruption.

\section{Quantifying and Contextualizing Changes in Life Course Choices}

Gibraltar offers the unique opportunity to undertake a small-scale case study. Our goal to reconstruct aspects of the social, economic, and demographic changes in the population over a dynamic period of time benefits from rich archival resources detailing aspects of community life before, during, and after the border closure. Furthermore, in order to supplement the archival research with individual-level perceptions, a series of unstructured interviews were undertaken, where community members were asked to recount their understanding of the effects of a closing and opening border on community life, including aspects of marriage and reproduction.

Following the approach of Agadjanian and Makarova (2003), we gauge changes in the family-building choices in this community before, during and after the border closure, focusing in particular on two variants of a typical life course: i) women who marry, and then conceive and give birth to their first child ("marital conceivers'), and ii) women who conceive, then marry and give birth to their 
first child ('premarital conceivers'). A seemingly subtle reordering of events surrounding marriage and birth of the first child, these two variants offer the potential for important differences in life course decision making. Relative frequencies of premarital conceptions also provide indirect insights into any changes in sexual activity outside of marriage and contraceptive use. Given these different life course sequences, we examine marital behaviour (age at first marriage) among marital and premarital conceivers and the relative connection between marriage and first childbirth (notably, the length of the interval linking these two events).

A database of all first births occurring in the community from 1960-1996 ${ }^{1}$ was created through abstracting and linking the local hospital's birth register to a database of civil registration information for births and marriages. Since this study is concerned with the timing of early life course transitions, including premarital conceptions of the first child, in order to standardize comparisons with marital conceivers, we limited the analysis to first births among nulliparous women (i.e., women pregnant with their first child and with no history of prior miscarriage, stillbirth, or abortion). Since the maternity register included information on the gestational age of infants at birth, there was increased accuracy in gauging date at conception with respect to date at marriage (and offsetting potential misinterpretations stemming, for example, from a married couple who conceive shortly after marriage but give birth to a preterm child). It must be stressed that our marriage analysis does not include all marriages, but only those marriages among women who gave birth to their first child during the study period. We constructed five temporally-defined birth cohorts, based on the changing status of the border: pre-border closure (1960-69), early closure (1969-76), late closure (1979-85), early open (1985-90), and late open (199196). There is no doubt that communities can change over time with respect to opportunities, for example, in women's employment and education; we argue that in Gibraltar these changes were shaped by an even larger context, the politically-motivated border closure, which served to transform and shape the perception of the life course in this community.

\section{Community Life in Gibraltar}

Since its capture from Spain in 1704 Gibraltar was first a Crown Colony of England, later evolving into an 'overseas territory' by the late $20^{\text {th }}$ century (for Gibraltar's early history, see Benady, 1993; Benady, 1994; Finlayson, 1996; Hills, 1974; Jackson, 1990). Connected to Spain at its northern extremity via a sandy isthmus, the eastern, southern, and western aspects of Gibraltar meet with the Mediterranean Sea, the Straits of Gibraltar, and Gibraltar Bay. Overall, Gibraltar's landmass is a diminutive 6.5 square kilometers in size and, with a 
Stacie D. A. Burke and Lawrence A. Sawchuk

population just under 27,000 in 1991, Gibraltar is considered a small-scale urban center. Not surprisingly, the population exists under very crowded and congested conditions, but, according to Danby (1977), a tradition of high density living is ingrained in Gibraltar (and other Mediterranean towns) and is generally more socially acceptable than in the UK. Gibraltar is a predominantly Roman Catholic community. In 1991, 20,541 individuals, or $76.9 \%$ of the total population, self-identified as Catholic (Government of Gibraltar, 1991).

Life on the Rock is quite unique. Agricultural and large-scale industrial undertakings are not possible given an extremely small geographical size and limited local resources. As a result, Gibraltarians are largely dependent on imports, including food and petroleum, from other places with Spain and England being the main countries of supply. Tourism has become a mainstay of the economy. Besides the attraction of Gibraltar's many beaches and rich military and cultural history, large numbers of tourists are drawn to the competitive shopping (VAT-free) offered by this Mediterranean port and European Union member. An estimated 5.5 million tourists entered Gibraltar by land, sea, or air in 1995 alone (AS, 1995). With a decline in what was once a predominantly dockyard-related economy, efforts were well underway by the 1990s to develop Gibraltar in other sectors (for example, as a competitive worldwide offshore banking centre).

\section{The $15^{\text {th }}$ Siege of Gibraltar: Political Motivation and Social Isolation}

From 1969 to 1985, some 15 years, the international border and any form of communications (e.g., telephone) between Spain and Gibraltar remained closed in an event which would serve to redefine the lives of Gibraltarians in the mid$20^{\text {th }}$ century. Characterized as the " $15^{\text {th }}$ siege of Gibraltar" (Jackson, 1987), the border closure was part of a deeply-rooted Spanish irredentist campaign to gain sovereignty over Gibraltar; this objective was greatly intensified during General Franco's dictatorship of Spain (see Gold, 1994). At this time, antiquated attempts to take Gibraltar by force, as had been typical in the $18^{\text {th }}$ and $19^{\text {th }}$ centuries, were replaced by political and legal debate engaging the United Nations in the 1960s. Britain remained committed to respecting the wishes of Gibraltarians who had virtually unanimously voted their desire to remain under British sovereignty in the referendum of 1967. Given continuously failing talks at the United Nations and the steadfast commitment of Gibraltarians to remain British, a new strategy was invoked.

In 1969, in an attempt to strangle Gibraltar's economy, Spanish authorities closed the frontier separating linking Gibraltar and Spain. Gibraltar's long 


\section{Reproductive Choices in Gibraltar: A Case Study of a Community under Transition, 1960-1996}

dependence on other countries, including Spain, for provisions and labour force had become a point of irritation. In the words of one Spanish representative: "Economically speaking, Gibraltar cannot live without Spain. There it lives at the cost of Spain and constitutes a sort of cancer in the economy of our country" (PR, No. 166/67, 1967). By withdrawing Spanish labourers and goods, the Spanish government hoped that England would feel the burdens of supplying an isolated colony and come to view Gibraltar as an unwise investment. As difficult and costly as life became for Gibraltarians, local feelings of opposition to the prospect of being turned over to Spain remained deeply ingrained, especially given the ongoing Spanish Civil War and the strong desire not to trade in English democratic rule for a Spanish dictatorship. The stalemate persisted for 15 long years and, in the end, Spain never did gain possession of Gibraltar. Many felt the border was opened in 1985 because Spain was then seeking membership in the European Community (PR, 30 January, 1981).

Gibraltar became a vastly different community during the time the border was closed, as it was cut off from Europe's mainland and tourism dropped dramatically. For the first time in Gibraltar's history the community had to learn to live with long-term isolation, existing in a similar fashion to many of the world's island communities. Gibraltar was even featured in a literary series on 'Islands,' even though political circumstance and not geographical reality produced this unique status (see Dennis, 1977). Many felt that the border closure caused the community to turn inward, producing a more family-like and insular community. As one Gibraltarian described it,

People used to just drive around in their cars, have little televisions, go and sit by the waterside or whatever and it was very strange how people looked at things...everybody was feeling like they were these dogs on chains. Then all of a sudden [when the border opened] this family-feeling that used to be was gone.

When the border opened in 1985, one Gibraltarian commented that it was almost like the community was being pulled out of the Victorian age, with tourists returning in increasing numbers and the resumption of social and economic communication with Spain. Within the context of the life course, three main areas were affected by the social, political, and economic changes which were fuelled by the closing and eventual re-opening of the border, including women's employment, education, and access to housing. The next three sections focus on each of these areas. 
Stacie D. A. Burke and Lawrence A. Sawchuk

\section{Expanding Employment Opportunities for Women in a Time of Social Change ${ }^{2}$}

Within the context of growing tensions between Spain and Gibraltar and the eventual closing of the border emerged significant changes in social and cultural views on the need for and value of women's employment outside the home. Changing employment patterns, in turn, can influence women's perceptions of community opportunity structure. For the first time in Gibraltar's history, an interesting chronology of events would transpire to revolutionize the position of Gibraltarian women in the local workforce, and it all seemed to begin with the Spanish Government's decision to stop issuing new permits for work in Gibraltar in 1954. Influenced by the law of supply and demand, Spanish workers who were still in possession of valid work permits could continue their employment in Gibraltar and, now that they were more limited in number, felt it was safe to begin demanding higher wages. As a result, local employers considered the merits of replacing positions formerly filled by Spanish workers with local women where possible, particularly in the catering industry. Local authorities encouraged this transition, feeling that the employment of Gibraltarian women "would not only bring better living standards to an increasing number of Gibraltarian families but would also tend to lessen [their] dependence on external sources of labour and increase the proportion of wages spent within the Colony" (AR DLW, 1956:22).

By the early 1960s Gibraltar's labour force encountered additional problems as the demographic effects of the war-time evacuation ${ }^{3}$ began to impact on the population. As early as 1958 the Government expected a continued fall in the number of young persons entering employment as the cohort associated with the abnormally low war-time birth rate began to reach employment age (AR DLSS, 1958:32). The Government, therefore, had even more reason to encourage Gibraltarian women and Gibraltarian teenagers into the workforce, which they did in increasing numbers beginning in 1959 (AR, 1961:7). Despite these gains, census returns for 1961 indicated that some 4,598 married Gibraltarian women were not registered in any type of paid employment outside of the home. Married women, for the most part, chose not to work outside of the home, largely because of childcare demands in the home (Government of Gibraltar, 1961:11).

Unmarried women employed with the 'Official Employers' typically worked as nurses, nursing/medical auxiliaries, teachers, clerks, storekeepers, typists, cleaners, laundresses, or in institutional domestic service in Officers' and NonCommissioned Officers' Messes. ${ }^{4}$ Those women seeking work from 'Private Industry Employers' typically worked in the distributive trade as shop assistants and cashiers, as hotel workers, waitresses or counter staff in the hotel and 
catering trade, as office assistants in professional and commercial businesses, in laundries and dry cleaning establishments, in tailoring and dressmaking, or in any of the few small factories on the Rock (AR DLSS, 1963: 46). Gibraltarian women's new-found position in the local workforce was further strengthened in 1965 when all married Spanish women were required (by Spanish authorities) to surrender their work permits, effectively removing them from the Gibraltar workforce (AR, 1965:12).

On the $6^{\text {th }}$ of August, 1966 all female Spanish frontier workers, about 2,000 women, were denied entry into Gibraltar by Spanish authorities (AR DLSS, 1965-66:14). There was no advance notice and, as a result, Gibraltar was not well-prepared. Spanish authorities stated that the women had been withheld at the frontier owing to reputed claims over police brutality in Gibraltar (PR 1967:170/67). Since the functioning of hospitals, schools, and nursing homes was largely dependent on the now missing Spanish labour force, "many Gibraltarian women, most of them with family responsibilities, who previously were not attracted to employment, offered their services" (AR DLSS, 196566:14). While initially working on an emergency voluntary basis, some women eventually took up permanent employment.

Government authorities believed that the contribution of married women's income to the household was a welcome addition (AR, 1966:5). ${ }^{5}$ Recognizing an opportunity to actively encourage women's continued interests in working, a number of employers opted to create new part-time positions. The demand for labourers also occasioned a general rise in women's wages (AR DLSS, 196566:14). By 1967, when the full effects of the dwindling supply of Spanish labour became apparent, an independent financial commissioner who had come to review Gibraltar's pay structure commented that "a strong case [existed] for making employment generally more financially lucrative to women" (Marsh, 1967:10).

When the Spanish government proceeded to enforce a full border closure in 1969, the Gibraltar government, scrambling to maintain a sufficient workforce, commissioned a 'Manpower Mission Report' from which it was determined that there was a "largely untapped group" of several thousand married women who were not working because they had pre-school age children. According to the report, "opinion [was] very divided about the social desirability of encouraging a higher rate of employment in this group, but, because of the compactness of the city, the effects upon family life of mothers going out to work [were not necessarily] as great as they [were] in other situations" (PR, 1969:162/69:6). They had uncovered a "particular...reluctance to provide day nurseries to enable mothers with young children to work, although representatives of the 
Housewives Guild suggested that a need for such provision [existed]," and the report supported this action (PR, 1969:162/69:6).

Determined to encourage married women to the workforce, the first Government Nursery opened late in 1969, accommodating 20 children in its first year (AR, 1969:31). There were also other signs that the government was sensitive to the particular needs of this new class of working married women. In the 1960s, for example, health officials grew concerned over the fact that working mothers were beginning to miss regular attendances at the infant weighing clinics (ARH, 1966). As a result, special arrangements were made for home visiting for working mothers (ARH, 1967).

In effect, it was the changing relations between Spain and Gibraltar which encouraged women, including married women, into the workforce. With such a great demand for workers, many women could find positions quite readily and with little prior training or extended education. After the border with Spain opened, and with complex changes to Gibraltar's economy between the 1980s and 1990s (including a marked downsizing in the dockyard and military presence), a more competitive economy emerged. The white-collar sector expanded, demanding greater educational investments of the workforce. Even at the entry level, competition with returning Spanish workers meant that employment opportunities no longer abounded as they had when the border was closed. Women who were once strongly encouraged to enter the labour force then found themselves competing for employment with other women, with men, and with foreign workers.

\section{Expanding Opportunities for Extended Education}

Beginning in 1950 education became a government responsibility and a local Board of Education was established. Initially, the secondary education of Gibraltarian students fell principally under the purview of the Roman Catholic Church. Continuing into the 1960s, schools retained " ... a very high standard of religious observance and a great awareness of moral values" with religious instruction embedded in the educational imperative (AR, 1961:36). A system of separate secondary schools for male and female students (beginning at 12 years of age) continued to operate in Gibraltar over the study period. Until the early 1970 s the government administered streamlining tests at 11 years of age to determine which students were destined for advanced (grammar) education. A system of Comprehensive education was instituted in 1971 so that all students remained grouped together under a single system and decisions regarding more advanced education were delayed. By the late 1970s, trends were showing increasing numbers of Gibraltarian teenagers choosing to remain in school past 
the normal school-leaving age of 15 years (ARDE, 1978-80:10). While an estimated $60 \%$ opted to remain in school past 15 in 1975, the proportion had risen to $75 \%$ in 1983 . The number of students choosing to pursue higher levels of education also increased. While only $35 \%$ of the sixth form age group opted to remain in school in 1979 (the sixth form is the most advanced level of education, preparing students for ' $\mathrm{A}$ ' level exams), approximately $60 \%$ opted to stay on in sixth form in 1983 (ARDE, 1982-83:11). Numbers would continue to rise as the government revolutionized the scholarship system in the late 1980s, allowing increasing numbers of students to attend university abroad (though families were still expected to assume part of the financial burden). It should be noted that pregnancies among female students during the study period effectively ended their Comprehensive education (the Board of Education did not allow pregnant students to continue in school). Within this context, pregnancy seriously compromised other life course decisions surrounding education and future employment.

\section{Housing and Home-Leaving Behaviour Among the Young}

Since home-leaving is often conceptualized as an important life course decision associated with the transition to young (and independent) adulthood and marriage (see Ravanera and Rajulton, 2006; Ravanera, Rajulton and Burch, 2003), it is critical to understand the housing context which existed in Gibraltar over much of the study period. In the decades between World War II and the 1980s Gibraltarians were greatly underhoused, often living in crowded multigenerational households. The situation only intensified with the border closure since the option to live in the Spanish hinterland and commute across the border to Gibraltar disappeared.

Historically, housing had always offered a struggle for Gibraltarians since it was in such short supply. In the 1960s, when the Ministry of Defense began to relinquish large tracts of reclaimed land (literally, land which had been 'reclaimed' from the shoreline through a process of backfilling), the government embarked on a series of large-scale housing construction projects in an attempt to reduce housing stress. When pressed to determine exactly how allocations would be made to Gibraltarian families for rentals in these sprawling new housing estates, architecturally a significant departure from pre-war 'patio'-style housing (see Sawchuk,1993), a housing wait list was established. Several factors were considered in awarding applicants basic points and balancing points and therefore determining their position on the wait list, including, for example: Gibraltarian status, degree of overcrowding, opposite-sexed children sharing the same bedroom, and emotional distress. Married couples were awarded more points than single applicants. The Government clearly 
Stacie D. A. Burke and Lawrence A. Sawchuk

recognized that the housing shortage was particularly burdensome for young and growing families. One survey published in 1960 reported that it would "be a very long time before young married couples [could] hope to obtain reasonable accommodation at a moderate rent" (Surridge, 1960:38). In most cases, married couples, perhaps with growing families, bided their time on the wait list while living in the homes of either the wives' or the husbands' families. In this context, home-leaving could not be conceptualized as a typical life course precursor to marriage, since it was an event rarely experienced by young adults.

As young Gibraltarian couples coped with the housing shortage and the wait list, a peculiar marriage strategy evolved. Though Gibraltar is a highly religious community, some couples opted to marry by a civil ceremony held at the Government Registry Office. This then allowed them to apply for housing as a married couple thereby earning more points and bumping them ahead of 'single' applicants. These couples did not generally recognize themselves as married, however, and partners would continue to live in their respective parental homes until they were later married in a church ceremony. The shortage of housing and the accepted and necessary tradition of extended family living persisted throughout the pre-border closure and border closure years. With no homes available for ownership, there was no real reason to be concerned about saving and planning, as indicated by one Gibraltarian's comments,

Everybody was getting married very, very early, really, because the only thing to 'plan for' ... was the wedding because they didn't have any [homes] to buy, they didn't have anything to furnish, everyone had a job, so people got married and immediately had a baby...had their families, because why wait? There wasn't any reason to wait.

This sentiment was echoed by many of the Gibraltarians interviewed who felt that people derived pleasure out of marrying and childbearing, particularly during the border closure, to escape the monotony of life on an 'island'.

Around the time the border opened in 1985 Gibraltar would see its first successful sales of government housing stock to Gibraltarian renters (or those eligible to apply for Government housing) (PR, 1985:22/85). By 1991, fueled by the economic growth after the border opened, land reclamation projects had increased Gibraltar's physical size by one-sixth (Government of Gibraltar, 1991) and the availability of Government- and privately-developed highrise accommodations on the new reclaimed land greatly expanded the housing pool available for rent and purchase. At this point, the concept of home ownership started to become a reality. We argue that a new concept of 'planning', 
particularly for home ownership, emerged at this time and served to influence the life course decisions made by young Gibraltarians entering into adulthood.

\section{The Changing Context of Marriage and Childbearing in Gibraltar: Focusing on the Rise in Premarital Conception}

Like other communities in Western Europe and North America, life course transitions in Gibraltar were likely fueled by a complex interaction of factors, some uniquely associated with the border closure and others more globally entrenched. The general liberalization of social-cultural norms which emerged in the 1960s and 1970s allowing for greater room in individual choices regarding sex and childbearing outside of marriage, as well as several other innovations, such as contraceptive technologies, were not lost on Gibraltar. While sexual relations outside of marriage may have changed, however, it would take much longer for contraceptives to become acceptable and available in Gibraltar, in part related to the high level of religiosity (mainly Catholicism) in this community. Many respondents reported that as contraceptives were introduced in Gibraltar, they were typically kept 'behind the counter' in drug stores and shops. Being such a small community, where anonymity is virtually unheard of, these contraceptives remained largely inaccessible, particularly to young, unmarried individuals. While Spanish shops offered some modicum of anonymity, the closed border effectively removed this option. The embarrassment, or even stigma, of purchasing contraceptives declined by the 1990s, particularly with the installation of coin-operated vending units in the bathrooms of some local establishments. It is also important to mention that therapeutic abortion has never been legalized in Gibraltar, thus increasing the probability that an unintended pregnancy would progress to the ultimate birth of the child.

Overall, $79.5 \%(n=2612)$ of married women who gave birth to their first child between 1960-1996 were married both at the time the child was conceived and at the time the child was born (marital conceivers) (Table 1). The remaining $20.5 \%(n=672)$ of women were married at the time the child was born but were unmarried when conception occurred (premarital conceivers). Bourgeois-Pichat (1986) would classify these marriages as "dependent marriages" since the union follows the conception of a child. As evident in the temporal breakdown in Table 1, there were two revolutionary changes in the reproductive choices of Gibraltarian women between 1960 and 1996. First, if the proportion of conceptions occurring outside of marriage can be taken as a proxy for some measure of sexual activity outside of marriage (particularly when contraceptives are not widely available), then there was an important change in this respect after the border closed in 1969 and the proportion of premarital conceptions 
increased dramatically from $10.8 \%$ in the pre-closure period to $21.6 \%$ of first births in the early closure cohort. The proportion has remained high ever since; the slight decline in the late open period (1991-96) can be accounted for by a rising number of women who become pregnant outside of marriage but opt not to marry before the birth. Such small numbers of women having extra-marital births before the 1990s precludes reporting here; suffice it to state that this alternate life course pathway is certainly growing in frequency among younger generations of women.

Table 1

Proportion of First Births Marital and Premarital Conceived Gibraltar: 1960-1996

\begin{tabular}{cccc}
\hline Birth Cohort & First Births & $\begin{array}{r}\text { Percent Marital } \\
\text { Conceptions (n) }\end{array}$ & $\begin{array}{r}\text { Percent Premarital } \\
\text { Conceptions (n) }\end{array}$ \\
Total & 3284 & $79.5(2612)$ & $20.5(672)$ \\
$\mathbf{1 9 6 0 - 1 9 6 9}$ & 886 & $89.2(790)$ & $10.8(96)$ \\
$\mathbf{1 9 6 9 - 1 9 7 6}$ & 719 & $78.4(564)$ & $21.6(155)$ \\
$\mathbf{1 9 7 9 - 1 9 8 5}$ & 588 & $76.2(448)$ & $23.8(140)$ \\
$\mathbf{1 9 8 5 - 1 9 9 0}$ & 532 & $71.8(382)$ & $28.2(150)$ \\
$\mathbf{1 9 9 1 - 1 9 9 6}$ & 559 & $76.6(428)$ & $23.4(131)$ \\
\hline
\end{tabular}

With respect to premarital conceivers, Cooksey (1990) suggests that marrying to 'legitimize' a pregnancy represents the most traditional (or culturallyconservative) choice a woman can make, since this action retains the normative link between the roles of wife and mother (and is quite distinct from the pathway chosen by women who choose not to marry). Given a general rise in extramarital births, it is evident that this normative link has weakened in Gibraltar since the border opened, likely through the effects of several community factors such as a rising level of divorce which is weakening the perceived link between marriage and parenting.

The high number of premarital conceptions must be viewed within the context of Gibraltar. Interviews with community members suggest that 'dating', in the broadest sense of the word, is not typical in the community (though this may not 
be as true for recent years). Over the study period, it was not uncommon for couples to begin courtships at young ages and quickly progress to highly committed and serious relationships involving the extended family (see Martens, 1987). Research in other communities has found involvement in committed relationships to be a strong predictor for sexual activity (see Small and Luster, 1994). Within this context, a premarital conception may simply serve to accelerate the timing of marriage among couples who are already committed to one another, with the event simply taking place sooner than later because of the baby on the way.

Examining marriage and childbearing behaviour among marital and premarital conceivers suggests that these two groups became increasingly different over the study period in terms of life course decisions, though these differences did not become significant until after the border opened in 1985. The temporal trend in mean at marriage among marital conceivers follows a general $U$-shaped pattern over time (see Table 2). Mean age at marriage is higher in both the pre-closure and late open cohorts with a significant drop in mean age during the border closure, particularly after many years of isolation in the late closure period. Women who conceived premaritally conformed, more or less, to the same $U$ shaped trend over time. This implies that premarital conceivers are responding to community-level or contextual cues guiding changes in age at marriage over time in the same manner as martially conceiving couples. The one important difference which does distinguish premarital conceivers, however, is their consistently lower mean age at marriage, with premarital conceivers marrying when they are about 2.5 to 3 years younger than martial conceivers, in large part because this group is composed of a far greater proportion of women under 18 years of age.

In considering mother's average age at first birth for marital conceivers and premarital conceivers (see Table 3), it becomes apparent that both groups once again follow a general $\cup$-shaped pattern over time where a noticeable dip in age at first birth coincides with the border closure years. Premarital conceivers were significantly younger than marital conceivers at the time of their first birth over each of the cohorts. Relative to age at marriage, an even stronger association exists between young maternal age (under 18 years) at first birth and the likelihood that the child was premaritally conceived. In considering Table 3 it is important to note that the disparity in age at first birth between marital and premarital conceivers is growing larger over time. This implies that while there are fairly consistent age differences observed between marital and premarital conceivers with respect to marriage age (the first life course transition), there is a growing discrepancy forming with respect to age at first birth (the second life course transition). Premarital conceivers in the pre-closure period, for example, 
Table 2

Mother's Mean Age at Marriage: Marital and Premarital Conceivers in Gibraltar: 1960-1996

\begin{tabular}{|c|c|c|c|c|c|c|c|}
\hline \multirow{2}{*}{$\begin{array}{l}\text { Birth } \\
\text { Cohort }\end{array}$} & \multicolumn{3}{|c|}{ Marital Conceivers } & \multicolumn{3}{|c|}{ Premarital Conceivers } & \multirow[b]{2}{*}{$\begin{array}{l}\text { mean age } \\
\text { difference }\end{array}$} \\
\hline & $n$ & mean age & s.d. & $n$ & mean age & s.d. & \\
\hline 1960-69 & 790 & 22.87 & 3.78 & 96 & 20.32 & 4.40 & 2.55 \\
\hline 1969-76 & 564 & 21.62 & 3.63 & 155 & 18.57 & 2.72 & 3.05 \\
\hline 1979-85 & 448 & 20.95 & 3.00 & 140 & 18.19 & 2.36 & 2.77 \\
\hline 1985-90 & 382 & 21.59 & 3.34 & 150 & 18.91 & 3.14 & 2.68 \\
\hline 1991-96 & 428 & 22.26 & 3.54 & 131 & 19.60 & 3.41 & 2.67 \\
\hline
\end{tabular}

Table 3

Mother's Mean Age at First Birth: Marital and Premarital Conceivers in Gibraltar: 1960-1996

\begin{tabular}{|c|c|c|c|c|c|c|c|}
\hline \multirow{2}{*}{$\begin{array}{l}\text { Birth } \\
\text { Cohort }\end{array}$} & \multicolumn{3}{|c|}{ Marital Conceivers } & \multicolumn{3}{|c|}{ Premarital Conceivers } & \multirow[b]{2}{*}{$\begin{array}{l}\text { mean age } \\
\text { difference }\end{array}$} \\
\hline & $n$ & mean age & s.d. & $N$ & mean age & s.d. & \\
\hline $1960-69$ & 790 & 24.71 & 4.14 & 96 & 20.93 & 4.29 & 3.78 \\
\hline $1969-76$ & 564 & 23.56 & 3.78 & 155 & 19.23 & 2.67 & 4.33 \\
\hline 1979-85 & 448 & 23.66 & 3.49 & 140 & 18.76 & 2.42 & 4.89 \\
\hline $1985-90$ & 382 & 24.82 & 3.60 & 150 & 19.50 & 3.22 & 5.32 \\
\hline 1991-96 & 428 & 25.54 & 3.62 & 131 & 20.05 & 3.52 & 5.49 \\
\hline
\end{tabular}




\section{Reproductive Choices in Gibraltar: A Case Study of a Community under Transition, 1960-1996}

bore their first children just over three and a half years earlier than marital conceivers. By the latest cohort, with marital conceivers averaging 25.5 years at first childbirth and premarital conceivers averaging 20 years at first childbirth, the differential had widened to a remarkable five and a half years.

Much of the discrepancy in age at first birth can be explained by the interval between marriage and conception. It is clear that the mean interval between marriage and conception has been steadily increasing over time for marital conceivers (see Table 4). Changes in mean interval for marital conceivers show significant shifts in family planning behaviour occurring in the late border closure and into the early and late open periods of the 1980s and 1990s. In both the pre-closure cohort and the early closure cohort, an interval of approximately 11 to 12 months elapsed from the time marital conceivers married and then conceived. By the late border closure couples were waiting significantly longer, averaging 23 months between marriage and conception. With the opening of the border the behaviour of married couples shifted once again as they began to delay conception from between 29 to 31 months after marriage. Such dramatic and linearly arranged increases in the marriage-conception interval are most likely the result of changing access to and acceptance of reliable contraceptives paired with a growing desire to delay the birth of the first child.

Premarital conceivers are represented by negative mean interval values since, on average, they conceived between 3.5 to 4 months prior to marriage. As opposed to marital conceivers, there has been no significant shift in this interval over time. This is to be expected, however, since it is really the timing of the conception which dictates the timing of marriage. An examination of the mean interval differences in Table 4 indicates that, as time unfolded and marital conceivers allowed for an increasingly longer interval after marriage to conceive, premarital conceivers (by virtue of being premarital conceivers) continued to have their first child very quickly after marriage. With a difference of just over a year in the 1960-69 pre-closure period, marital conceivers in the 1990s waited an average of 3 years longer than premarital conceivers to conceive their first child.

What are the implications of these findings and what does the marital conceivers interval tell us? While already older on average to begin with, marital conceivers began to allow increasingly more time before initiating family building. In the interval, couples could adapt to married life, taking on the roles of wife and husband well before the roles of mother and father. Couples had a longer period of time to work without bearing the financial burden of a first child, enabling them to establish greater economic security. Unlike the earliest 
Stacie D. A. Burke and Lawrence A. Sawchuk

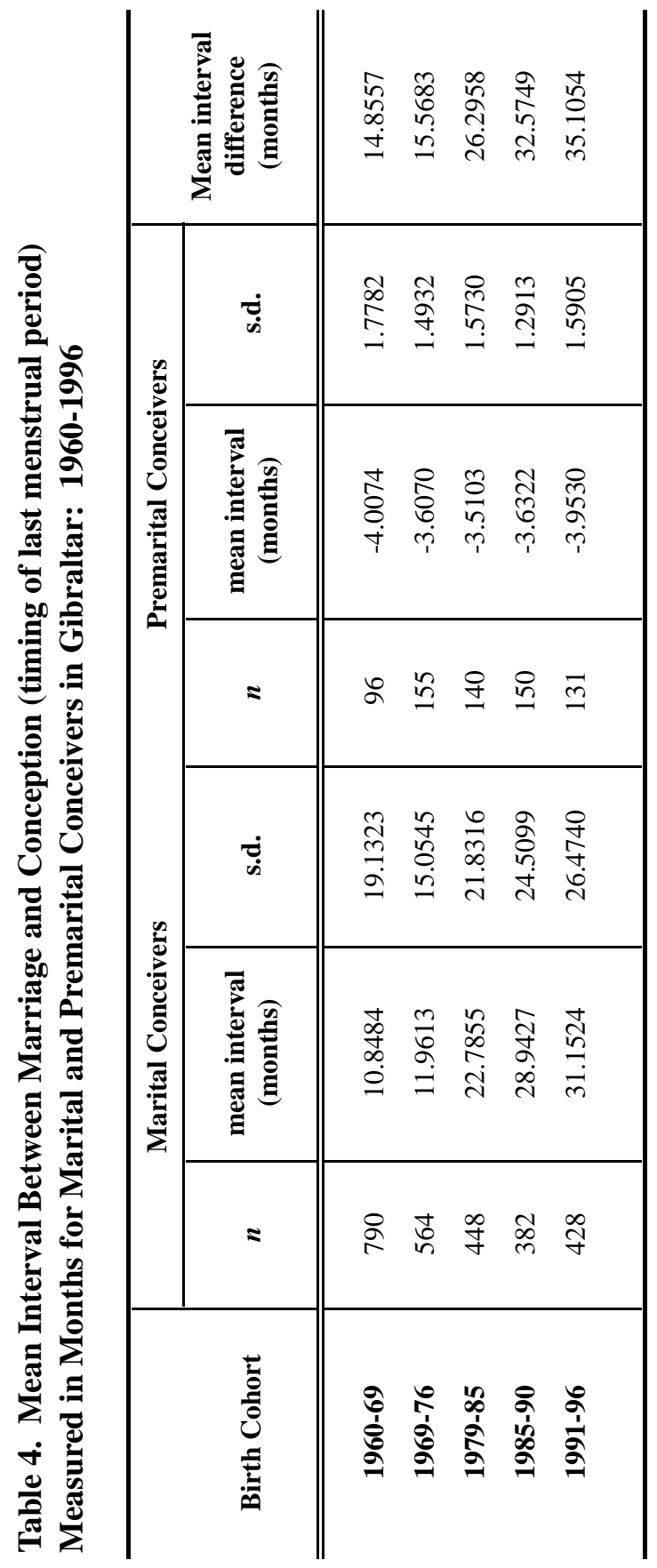

CSP 2007, 34.2: 149-178 


\section{Reproductive Choices in Gibraltar: \\ A Case Study of a Community under Transition, 1960-1996}

cohorts, marriage in was no longer equated with immediate childbearing, suggesting a growing motivation for strategic family planning.

Adopting Carmichael's (1996) strategy, insights into the social and cultural dimensions of premarital pregnancy can be drawn through an examination of the length of the interval between conception and resolution by marriage among premarital conceivers. Carmichael (1996) suggests that couples who marry very soon after conception, so that the woman experiences the majority of her pregnancy as a married woman, may have either initiated sexual relations in anticipation of a forthcoming marriage or simply bumped their marriage plans ahead of schedule. In comparison, those who take longer to marry may not have been as prepared in the life course for an easy movement into marriage, perhaps if a woman is younger. In Gibraltar, of the 672 premarital conceivers in the sample, 68\% married within 3 months of conception (i.e., in the first trimester) (Table 5). Of those remaining, 28\% married between 4 to 6 months after conception and only $4 \%$ waited until the late stages of pregnancy ( 7 to 9 months) to marry.

Early marriages remain quite consistent through time. In other words, Gibraltarian families seem to maintain the pattern of quick marriage to resolve premarital pregnancies consistently over time, a tendency likely facilitated by the preference for committed courtships among young unmarried couples. Table 6 considers the nature of the interval when maternal age is taken into account, since pregnancies among women under 18 years of age, who are at earlier stages in their life course and in a less common age range for marriage, may take longer to resolve the issue of a premarital pregnancy. This does appear to be the case with significantly more women under 18 waiting 4 to 6 months (the second trimester) to marry relative to their older counterparts. By Carmichael's (1996) understanding, younger women may wait longer because they are less likely to have discussed marriage plans with their partners prior to the pregnancy and so must first agree to marry before planning for the wedding.

\section{Marital and Premarital Conception: Two Variants on a Life Course}

Though premarital conception emerged as a significant feature of life in Gibraltar after the border closed in 1969, it did so within a unique setting. Existing as a virtual 'island' community for some 15 years, marriage patterns adapted to the distinctive social and economic climate which ensued. Age at marriage dropped, at least in part, because Gibraltarians saw small benefits to delay (Sawchuk, 1992). When the border closed and Gibraltar suffered a major 
Stacie D. A. Burke and Lawrence A. Sawchuk

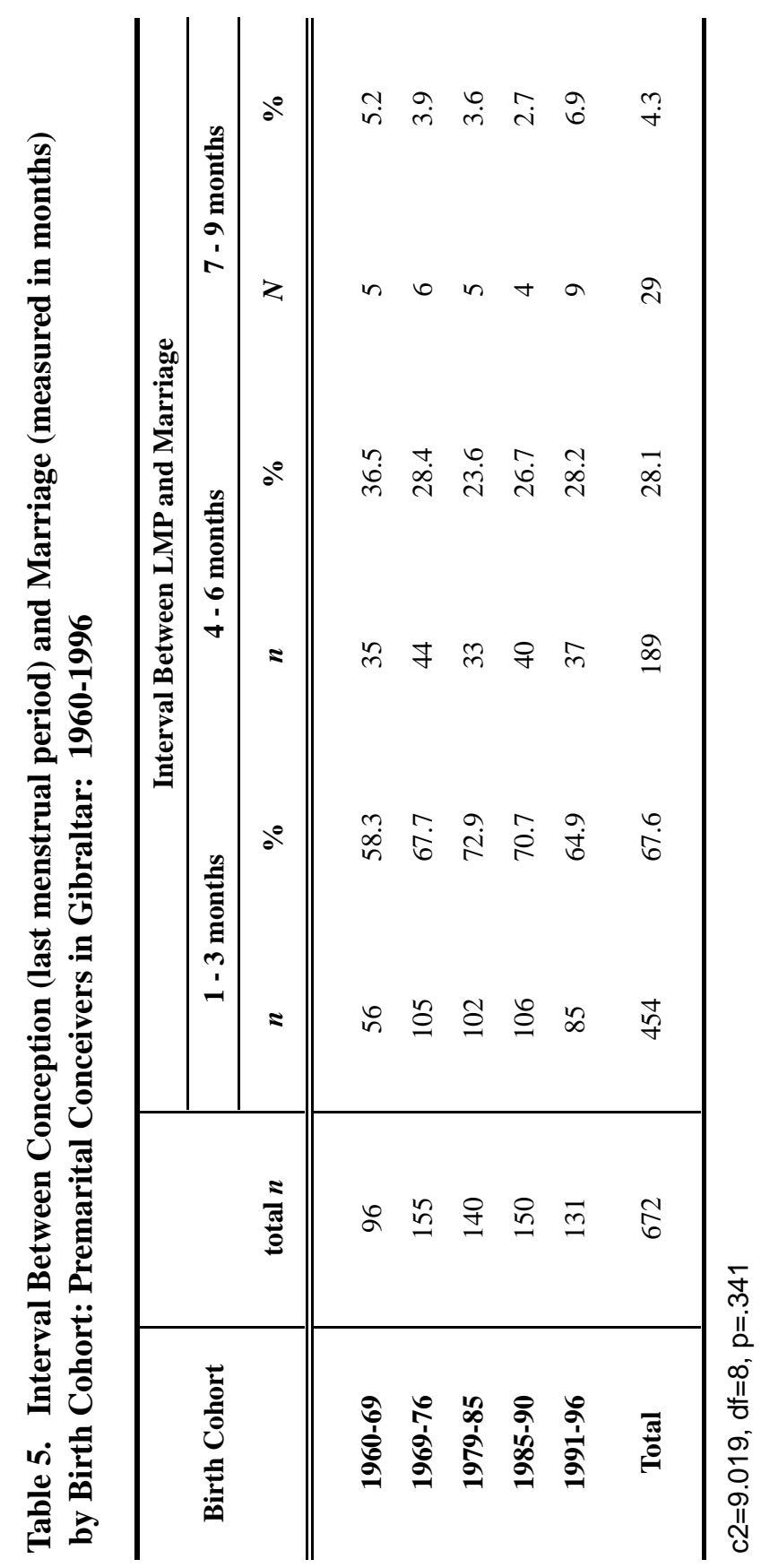

CSP 2007, 34.2: 149-178 
Reproductive Choices in Gibralter:

A Case Study of a Community Under Transition, 1960-1996

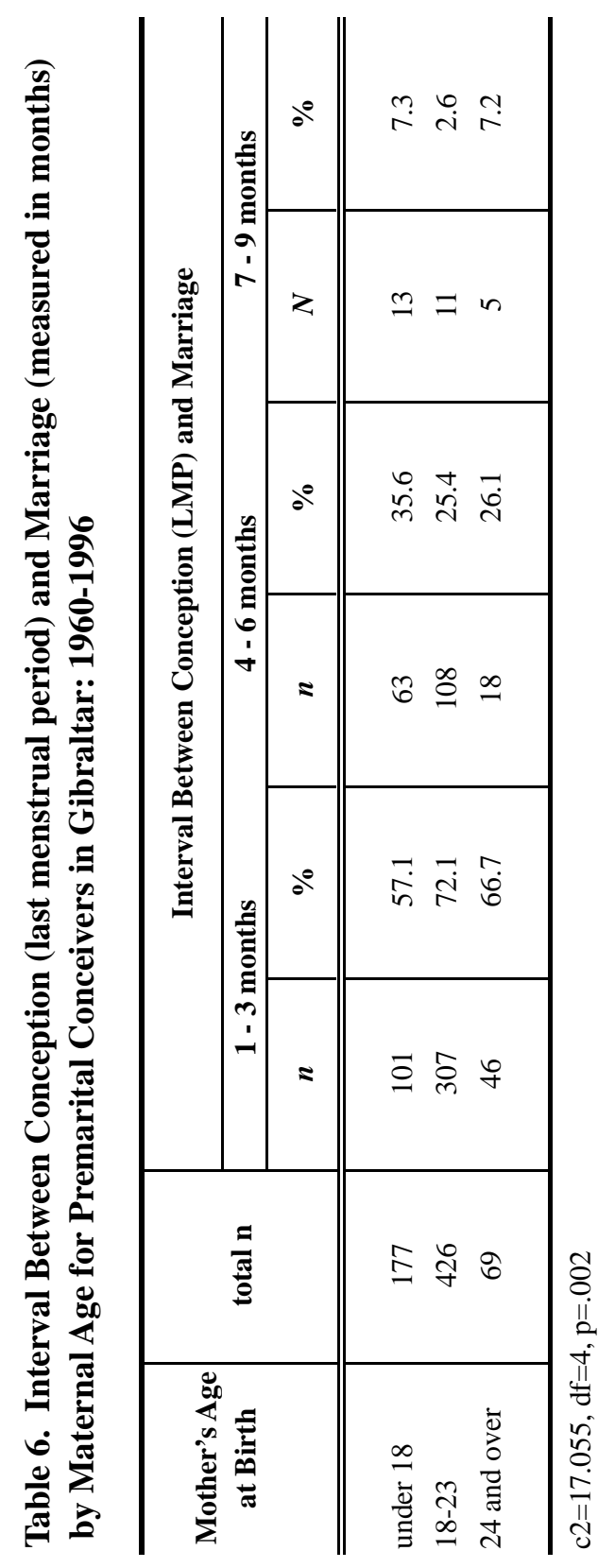


labour shortage owing to the complete withdrawal of all Spanish employees, it was not hard for young Gibraltarians to find employment, even if they did not have a strong educational background. The availability of employment for young men and the encouragement of women into paid employment increased the earning capacity of local families and, under such conditions, made early marriage more feasible. As one Gibraltarian indicated, there was really very little to plan for in any case:

...before you just got married and had children [right away]...because you didn't plan...like nowadays they get married and say 'Oh, no, I need to pay my mortgage first' or 'I need to get my car' or 'I need to go on holiday, I want to go on holiday first'...before, no, they didn't think about that...they got bored and they had children and then, you know, it was something to keep them going.

As Gibraltar became quite insular when the border closed, many of those interviewed repeated this theme - that marriage and parenting, qualities already valued in the community, kept life interesting. During this time, marital and premarital conceivers of the border closure cohorts differed very little - both married young, and though the marital conceivers were beginning to delay the birth of their first child somewhat by the late closure cohort, both had their first children at relatively younger ages.

Real differences in the life course decisions of marital and premarital conceivers emerged after the border opened, but these differences cannot be conceptualized by overall increasing disparities in age at marriage and age at first birth, the two fundamental life course transitions under examination here. While marital conceivers do become significantly older than premarital conceivers at the time of their first child's birth, there are no appreciable changes in the disparities in age at marriage (though marital conceivers are older at marriage, the relative age difference with premarital conceivers changes very little between 1960 and1996). This implies that in plotting the path of life course changes, those following the more normatively prescribed pathway of marriage $\rightarrow$ conception $\rightarrow$ first birth are more likely to delay the birth of child than they are to delay the marriage to any significant extent. Overall, early marriage remains favoured in Gibraltar (see Table 7). Even if some of these marriages can be accounted for by the strategic Registry marriages (followed later by a religious wedding), this still intimates a desire to establish the marital union at an early age. In conceptualizing life course events in Gibraltar, normative pathways must take into consideration the high cultural value placed on marriage and the possibility that this might reorder, or even preclude, other life course events such as education, if necessary. While the timing of the birth of 


\section{Reproductive Choices in Gibraltar: A Case Study of a Community under Transition, 1960-1996}

the first child appears subject to temporal forces, early marriage, as a life event, is far more ingrained.

The possible reasons for the delay of the first child could be tied to personal objectives since women now had greater investment (through education) and interest in remaining in the paid workforce for some time before the first baby was born. Married couples could also indulge in more strategic economic planning regarding housing (perhaps even saving for a mortgage), before the first baby came along. These new opportunities for housing, virtually unheard of in Gibraltar's long history of multigenerational homes, grew significantly after the border opened. Towards the end of the $20^{\text {th }}$ century, the local Government was offering many attractive incentives to assist Gibraltarians in home purchase, a possibility particularly feasible for the middle-class (higher SES families had always been able to fend for themselves; lower SES families remained relatively more reliant on rental housing).

Since the border opened, with the deeper history of the movement of women into employment paired with the new opportunities for well-trained women in higher-paying career-type employment, revised priorities and objectives formed among middle-class women with respect to the value of extending education and planning for home ownership (and doing so with their partners),

Girls now have to look around and say 'Right, where are we going to live...we have to save for this,' as everybody does, so that having got married, having got their homes, they're also wanting to have some time together...then they will have their baby...so many of these babies [now] are planned, the first ones...they have an expression here because it's been translated from the Spanish and it is 'We will send for a baby.'

Furthermore, the concept of being 'locked into' a mortgage is redefining the flexibility Gibraltarians see in terms of their lifetime family planning,

They're thinking more about themselves. They think now I've got a house, I've just spent a fortune getting my house for example, I've got three rooms, which is one for each of the children and one for myself...so we definitely have no more room for any more children, we can't afford to go and buy ourselves another house...so we're going to have to opt for this, this is the two. 
Table 7

Comparative Estimates of Female Mean Age

at First Marriage for

Gibraltar and Selected Countries; 1991-1996

\begin{tabular}{l|c|c}
\hline \multicolumn{1}{c|}{ Country } & Year & $\begin{array}{c}\text { Female Mean Age at } \\
\text { First Marriage }\end{array}$ \\
\hline \hline Finland & & \\
Germany & 1996 & 29.6 \\
Ireland & 1996 & 29.0 \\
France & 1996 & 28.7 \\
Australia & 1990 & 27.7 \\
United Kingdom & 1994 & 27.0 \\
Morocco & 1991 & 26.4 \\
Canada & 1995 & 26.3 \\
Italy & 1994 & 26.2 \\
Spain & 1991 & 26.1 \\
Austria & 1991 & 26.1 \\
United States & 1991 & 26.1 \\
Denmark & 1995 & 26.0 \\
Greece & 1995 & 25.0 \\
Portugal & 1991 & 24.5 \\
Croatia & 1991 & 23.9 \\
Gibraltar & 1991 & 23.8 \\
Switzerland & $1991-1996$ & 23.0 \\
& 1994 & 22.4 \\
\hline Winther & & \\
\hline
\end{tabular}

a. With the exception of Gibraltar, data from United Nations 'World Marriage Patterns 2000",

see: www.un.org/esa/population/publications/worldmarriagepatterns2000.pdf. Estimates are based on calculation of singulate mean age at marriage (SMAM). Countries varied by the year for which data were presented.

b. Calculations based on civil registration, Government of Gibraltar (excludes non-resident women and women previously married).

A small number of women over 50 years of age at first marriage are removed to maintain compatibility with SMAM estimates which are truncated at age 50 (if these women were included, mean age at marriage would be 23.3). 


\section{Reproductive Choices in Gibraltar: A Case Study of a Community under Transition, 1960-1996}

While the goal of home ownership appealed to many middle-class Gibraltarians and was clearly an important factor influencing decisions surrounding childbearing, it is evident that after the border opened there was a growing dichotomy between marital conceivers who delayed the birth of their first child and premarital conceivers who followed a different route.

It would be no easy task to account for why premarital conceivers followed this different life course. It is possible that the opportunities for extended education abroad and the resources necessary to enter into home ownership may not have been perceived as equal opportunities for all. Of the 672 men involved in premarital conceptions in Gibraltar, 442 (65.7\%) held positions in manual labour (skilled and unskilled) at the time of their child's birth, likely the reflection both of young paternal age and a lack of extended education. If the community opportunity structure was viewed differently by middle-class and working-class families, it is possible that young women who conceived premaritally conceptualize their life course according to the more traditional, yet highly culturally-valued, roles of wife and mother. According to Cooksey (1990:208), when teenage women perceive poor employment possibilities, motherhood may hold higher value because it "confers a status less easily achieved by other means, for example, a job." When employment and careers opportunities are good, however, motherhood may be more aptly perceived as a risk to attaining those goals. Many premarital conceivers make this decision early in the life course, becoming pregnant at younger ages and potentially sacrificing the opportunity to complete Comprehensive (high school) education.

Female premarital conceivers in the 1990s were an average 5.5 years younger than their martially-conceiving counterparts. While premarital conception and having a child at a young age may not have had a tremendous impact on family well-being during the border closure (even marital conceivers were doing it), changing social and economic implications will likely emerge in the competitive world of the open border.

\section{Conclusions}

This research stresses the importance of examining life course choices within the context of the community's changing ecological setting and the powerful role of political disturbances in structuring those changes. Our findings suggest that women in Gibraltar were willing to delay childbearing, and perhaps forego extended education, but they were not as flexible regarding delaying marriage. This is perhaps why marriage ages remain relatively low in comparison with other populations in the 1990s and why marriage ages seem to change very little over time, despite large-scale changes in the economy and women's positions in 
Stacie D. A. Burke and Lawrence A. Sawchuk

the economy. The small changes in marriage stand in contrast to the much larger changes in age at first birth resulting from the increasing delay of the first birth. This is where premarital conceivers differ in the greatest respect in comparison to marital conceivers. They may be marrying slightly earlier, but, by the late 1980s and 1990s, the biggest difference is really in the short interval between marriage and first birth. Marital conceivers would seem to be adopting an increasingly distinct pathway in terms of the life course - increasingly delaying the birth of the first child into the union, while premarital conceivers continue to give birth to their first child very soon after marriage. It is possible that these different trajectories may be grounded in distinctly different perceptions concerning the community opportunity structure and what the individual and couple desires to achieve prior to the birth of the first child (e.g., working and saving for housing) and the value placed on those personal and material goals in relation to the value placed on motherhood.

\section{Acknowledgements:}

The authors are grateful to the journal's three anonymous reviewers for their insightful comments and suggestions.

\section{End Notes:}

1. With the exception of births between October, 1976 and May, 1979 where data was not available

2. It should be noted that, along with encouraging women into the workforce, the border closure also resulted in a large number of Moroccan workers entering Gibraltar to replace the lost Spanish workforce.

3. All women, children, and non-able-bodied men were evacuated during World War II; they were evacuated in 1940, and the last repatriated in 1951 (see Finlayson, 1996).

4. It should be noted that working in domestic service for the Official Employers did not carry as great a stigma among Gibraltarian women as working in domestic service for private families, which they tended to avoid despite the good pay.

5. Many families were struggling with the high cost of living in Gibraltar.

In 1967, it was estimated that about $50 \%$ of poorer families' income was 
Reproductive Choices in Gibraltar:

A Case Study of a Community under Transition, 1960-1996

spent on foodstuffs alone, even though the Government maintained close control over the price of basic necessities such as butter, cooking oil, tinned milk, fruits, and vegetables (Bottomley, 1967:4).

\section{References:}

Abstract of Statistics. 1995. Government of Gibraltar.

Agadjanian, V. and E. Makarova. 2003. "From Soviet Modernization to PostSoviet Transformation: Understanding Marriage and Fertility Dynamics in Uzbekistan," Development and Change, 34: 447-473.

Annual Report. 1961, 1965, 1966, 1969. Government of Gibraltar.

Annual Report, Dept. Education. 1978-1980, 1982-1983. Government of Gibraltar.

Annual Report, Dept. Labour and Social Security. 1958, 1963, 1965/1966. Government of Gibraltar.

Annual Report, Dept. Labour and Welfare. 1952/1953, 1956. Government of Gibraltar.

Annual Report on the Health of Gibraltar. 1966, 1967. Government of Gibraltar.

Benady, S. 1994. Civil Hospital and Epidemics in Gibraltar. Grendon, Northants: Gibraltar Books Ltd.

Benady, T. 1993. The Royal Navy at Gibraltar. Grendon, Northants: Gibraltar Books Ltd.

Billy, J.O., K.L. Brewster, and W.R. Grady. 1994. "Contextual Effects on the Sexual Behavior of Adolescent Women," Journal of Marriage and the Family, 56: 387-404.

Bottomley, T.N. 1967. Gibraltar Co-Operative Report (directed to the Permanent Secretary, Ministry of Overseas Development, London). Gibraltar Government Archives. 
Stacie D. A. Burke and Lawrence A. Sawchuk

Bourgeois-Pichat, J. 1986. "The Unprecedented Shortage of Births in Europe," in Below-Replacement Fertility in Industrial Societies edited by K. Davis, M.S. Bernstam, and R. Ricardo-Campbell. Cambridge: Cambridge University Press.

Carmichael, G.A. 1996. "From Floating Brothels to Suburban Semirespectibility: Two Centuries of Nonmarital Pregnancy in Australia," Journal of Family History, 21: 281-315.

Cooksey, E.C. 1990. "Factors in the Resolution of Adolescent Premarital Pregnancies,” Demography, 27: 207-218.

Cooksey, E.C., R.R. Rindfuss, and D.K. Guilkey. 1996. “The Initiation of Adolescent Sexual and Contraceptive Behavior During Changing Times," Journal of Health and Social Behavior, 37: 59-74.

Danby, M. 1977. Construction of Glacis Estate, Phase II, Gibraltar: An ExPost Evaluation (England: Cambridge Archives).

Dennis, P. 1977. Gibraltar. North Pomfret, Vermont: David and Charles.

Finlayson, T.J. 1996. The Fortress Came First: The Story of the Civilian Population of Gibraltar During the Second World War. Grendon, Northants: Gibraltar Books Ltd.

Gold, P. 1994. A Stone in Spain's Shoe: The Search for a Solution to the Problem of Gibraltar. Liverpool: Liverpool University Press.

Government of Gibraltar. 1961. Report on the Census of Gibraltar, Taken on $3^{\text {rd }}$ October, 1961 (E.H. Davis, Census Commissioner). Printed at the Garrison Library Printing Office.

Government of Gibraltar. 1991. Census of Gibraltar, 1991 (H.A. Fell, Census Commissioner). C.G. Trico (Printers) Ltd.

Haldre, K., H. Karro, M. Rahu, and A. Tellmann. 2005. "Impact of Rapid Socioeconomic Changes on Teenage Pregnancies in Estonia during 19922001," Acta Obstetricia et Gynecologica Scandinavica, 84: 425-431.

Hills, G. 1974. Rock of Contention. London: Robert Hale. 
Reproductive Choices in Gibraltar:

A Case Study of a Community under Transition, 1960-1996

Hitztaler, S. 2004. "Changing Human Populations in Post-Soviet Kamchatka: An Integrated Study of Shifts in Fertility and Net Population,"

Population and Environment, 25: 335-354.

Jackson, W.G.F. 1987. The Rock of the Gibraltarians: A History of Gibraltar. Grendon, Northants: Gibraltar Books Ltd.

Kohler, H.-P. and I. Kohler. 2002. "Fertility Decline in Russia in the Early and Mid 1990s: The Role of Economic Uncertainty and Labour Market Crises," European Journal of Population, 18: 233-262.

Marsh, A.I. 1967. Gibraltar Pay Structure Review. Gibraltar Government Archives.

Martens, J.L. 1987. Gibraltar and the Gibraltarians. Unpublished Ph.D. thesis, University of London, England.

Press Release. 1967. No. 166/67. Speech delivered by Sir Joshua Hassan yesterday afternoon. Government Secretariat, Gibraltar Government Archives.

Press Release. 1967. No. 170/67. Fourth Committee - Gibraltar. Government Secretariat, Gibraltar Government Archives.

Press Release. 1969. No. 162/69. Government Secretariat, Gibraltar Government Archives.

Press Release. 1970. $1^{\text {st }}$ January. New Year Message by Chief Minister. Government Secretariat, Gibraltar Government Archives.

Press Release. 1981. 30 January, 1981. Extracts from a speech by the Secretary of State for Foreign and Commonwealth Affairs, Lord Carrington, in the House of Lords in Gibraltar on 28 January. Government Secretariat, Gibraltar Government Archives.

Press Release. 1985. No. 22/85. Government Secretariat, Gibraltar Government Archives.

Ravanera, Z. and F. Rajulton. 2006. "Social Status Polarization in the Timing and Trajectories to Motherhood," Canadian Studies in Population, 33: 179-207. 
Stacie D. A. Burke and Lawrence A. Sawchuk

Ravanera, Z., F. Rajulton, and T.K. Burch. 2003. "Early Life Transitions of Canadian Youth: Effects of Family Transformation and Community Characteristics," Canadian Studies in Population, 30: 327-353.

Sawchuk, L.A. 1993. "Societal and Ecological Determinants of Urban Health: A Case Study of Pre-Reproductive Mortality in $19^{\text {th }}$ Century Gibraltar," Social Science and Medicine, 36: 875-892.

Sawchuk, L.A. 1992. "Historical Intervention, Tradition, and Change: A Study of the Age at Marriage in Gibraltar, 1909-1983," Journal of Family History, 17: 69-94.

Scherbov, S. and H. Van Vianen. 2001. "Marriage and Fertility in Russia of Women Born between 1900 and 1960: A Cohort Analysis," European Journal of Population, 17: 281-294.

Small, S.A. and T. Luster. 1994. "Adolescent Sexual Activity: An Ecological, Risk-Factor Approach," Journal of Marriage and the Family, 56: 181192.

Stewart, J.D. 1967. Gibraltar, the Keystone. London: Murray. 